\title{
THE ULTRAFILTRABLE CALCIUM OF HUMAN SERUM. II. VARIATIONS IN DISEASE STATES AND UNDER EXPERIMENTAL CONDITIONS ${ }^{1}$
}

\author{
By A. RAYMOND TEREPKA, T. Y. TORIBARA, AND PRISCILLA A. DEWEY \\ (From the Department of Medicine and the Division of Pharmacology of the Department of \\ Radiation Biology, University of Rochester School of Medicine and \\ Dentistry, Rochester, $N . Y$.)
}

(Submitted for publication August 22, 1957 ; accepted September 12, 1957)

The total serum calcium is composed of two major fractions: the non-diffusible or protein bound calcium, and the diffusible or ultrafiltrable calcium. The latter, containing predominantly ionic calcium, theoretically traverses capillary membranes in vivo and participates in metabolic processes at the cellular level.

In a previous publication, a new simple method for the ultrafiltration of human serum was described (1). It was found that in normal adults, between 60 and 70 per cent of the calcium present in serum was ultrafiltrable. These findings were compared with the variable values reported by other authors for the normal percentage of ultrafiltrable calcium. It was pointed out that virtually all previous workers had failed to control both the $\mathrm{pH}$ and the temperature during their ultrafiltration procedures. Our data indicated that these variables had a considerable effect on the ultrafiltrability of serum calcium, thus offering an explanation for the lack of agreement, particularly among the early workers (2), in the study of normal and abnormal sera. Only the recent data of Hopkins, Connor, and Howard (3) show reasonable consistency for specific disease states. They used the Lavietes mercury-pressure ultrafiltration apparatus, controlled $\mathrm{pH}$, and carried out the ultrafiltration procedure at room temperature.

Utilizing the controlled technique previously described (1) we have reinvestigated the distribution of calcium in the serum of a group of patients with hypercalcemia and hypocalcemia. These results are given in the first portion of this communication. Although differing in the absolute quantity, and therefore the per cent of ultrafiltrable calcium, our findings are in agreement with those reported by Hopkins and her associates

\footnotetext{
1 This paper is based on work performed under contract with the United States Atomic Energy Commission at the University of Rochester Atomic Energy Project, Rochester, New York.
}

(3)..$^{2} \quad$ However, certain interesting observations in renal disease prompted us to investigate more closely the hypocalcemia associated with this condition.

The ultrafiltration method we have utilized requires relatively small quantities of serum ( $3 \mathrm{ml}$.). Thus, frequent determinations of ultrafiltrable calcium are possible during experimental procedures. To supplement the observations in disease states, a detailed investigation was made of acute hypercalcemia in human subjects induced by calcium infusion or parathyroid extract administration. In addition, hyperphosphatemia and hypercitremia, both considered to have specific effects on total or ultrafiltrable calcium, were induced experimentally and observations made on the distribution of calcium in serum. The results of these experiments are presented in the second portion of this paper.

\section{METHODS}

Patients on the general medical wards of the Strong Memorial Hospital with abnormal total serum calcium values were selected for the study of the distribution of serum calcium in disease states. A definite diagnosis was established clinically in all cases. Blood was collected by venipuncture in the non-fasting state and serum ultrafiltered the same day. Another patient, who was being studied on the metabolism ward of the Department of Medicine, served as the subject for the detailed investigation of the effect of experimentally induced conditions on the ultrafiltrability of serum calcium. $\mathrm{He}$ was a 75 year old white man with chronic lymphatic leukemia and an annular carcinoma of the rectosigmoid. In spite of the two malignant processes, he appeared well nourished (body weight, $63 \mathrm{Kg}$.) and was generally asymptomatic but did have slight hypoproteinemia. No evidence of bone involvement with cancer was apparent clinically, by X-ray or balance study.

2 The higher values for ultrafiltrable calcium in the studies of Hopkins, Connor, and Howard (3) probably resulted because these authors carried out their ultrafiltration procedures at room temperature instead of $37^{\circ} \mathrm{C}$. 
TABLE I

Ultrafiltration results and other pertinent data in patients with hypercalcemia and hypocalcemia

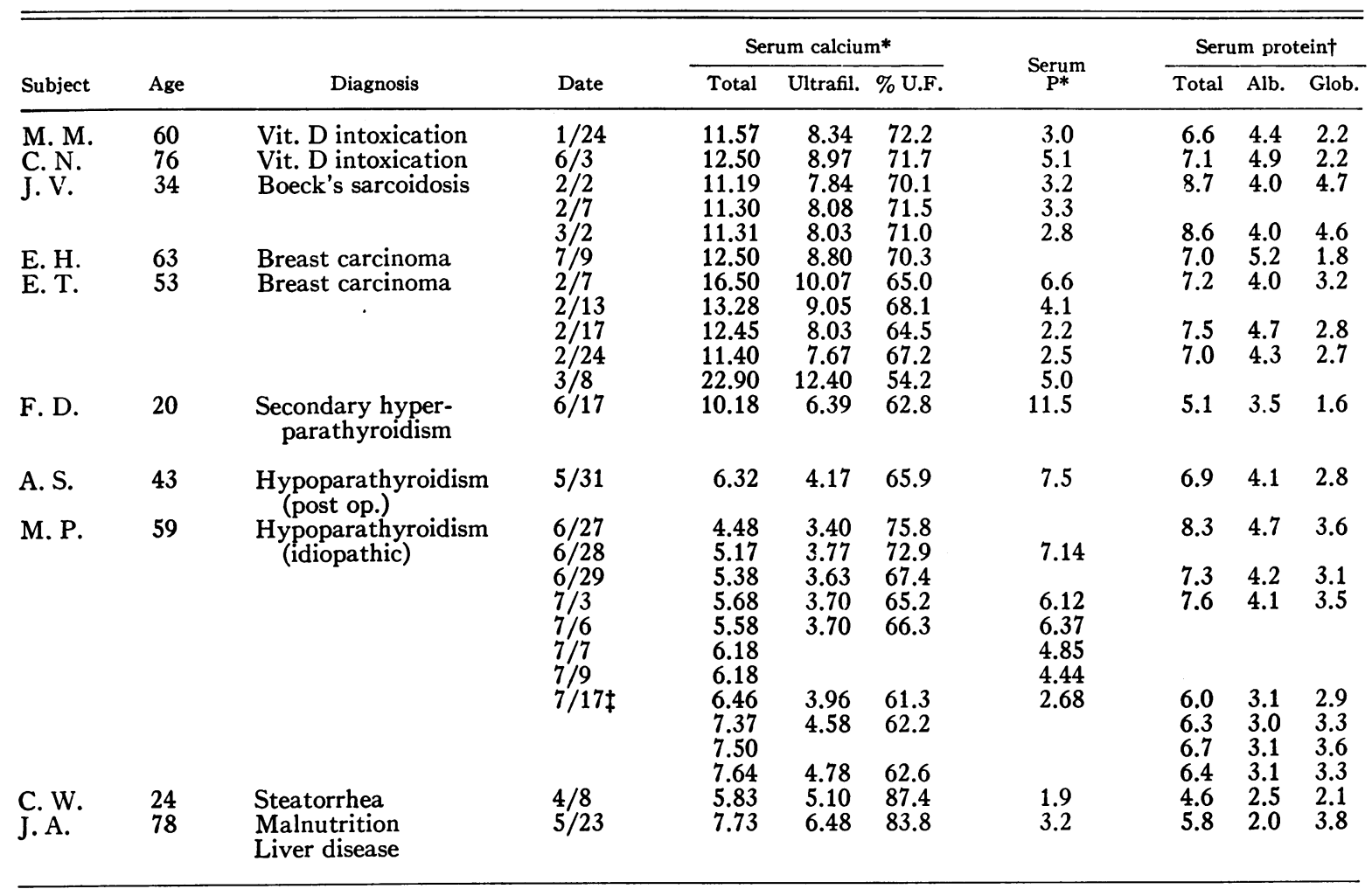

* Values in $\mathrm{mg}$. per cent.

$\dagger$ Values in $\mathrm{Gm}$. per cent.

$\ddagger$ Blood samples obtained at 9:00 a.m., 10:30 a.m., $11: 45$ a.m. and 2:00 p.m.

The procedure for the ultrafiltration of human serum was described in detail in a previous paper (1). All determinations were done at $36^{\circ}$ C. after equilibration of the apparatus with 5 per cent carbon dioxide and 95 per cent oxygen. Calcium was determined in both whole serum and the ultrafiltrates by a flame photometric technique (4). The normal range for total serum calcium and ultrafiltrable calcium by this method is 9.26 to 10.30 mg. per cent and 6.17 to $7.16 \mathrm{mg}$. per cent, respectively. The "per cent of ultrafiltrable calcium" was obtained by simply dividing the concentration of calcium in the ultrafiltrate by that in the whole serum (no protein correction) and multiplying by 100 per cent.

Inorganic phosphorus determinations on the serum of patients with hypocalcemia and hypercalcemia were done by the Fiske and Subbarow method (5) while the method of Chen, Toribara, and Warner (6) was used for the determination of total serum phosphorus and serum inorganic phosphorus in the patient studied on the metabolism ward and in patient M.P. (Table I) with idiopathic hypoparathyroidism. Total carbon dioxide content of serum and blood urea nitrogen were determined by the Van Slyke and Neill (7) and the Van Slyke and Cullen (8) methods, respectively. Fractionation of the serum proteins was carried out by a detergent technique
(9) and the serum citrate analyses were done by the method of Ettinger, Goldbaum, and Smith (10). ${ }^{3}$ The latter two methods give the following values for normal sera: total protein, 6.5 to $8.0 \mathrm{Gm}$. per cent; albumin, 4.5 to $5.5 \mathrm{Gm}$. per cent; total serum citrate, 3 to 5 mg. per cent.

\section{RESULTS}

\section{The serum ultrafiltrable calcium in disease states}

\section{A. Hypercalcemia}

The ultrafiltrable calcium in a variety of diseases associated with abnormalities in serum calcium are recorded in Tables $I$ and II along with other pertinent data. Normal human subjects have ultrafiltrable calciums ranging between 61.7 and 71.4 per cent of the total serum calcium (1) so that the concentration of ultrafiltrable calcium

${ }^{3}$ The authors are indebted to Dr. Ralph Jacox for the protein determinations and Betty Jane Mulryan for the citrate analyses. 
ranges between 6.2 and $7.2 \mathrm{mg}$. per cent. It can be seen in Table I that in the patients with hypervitaminosis $\mathrm{D}$, Boeck's sarcoidosis, and metastatic breast carcinoma with hypercalcemia, the concentration of ultrafiltrable calcium was distinctly elevated, while the percentage of the total serum calcium which was ultrafiltrable was in, or only slightly above, the normal range. These patients tended to have mild degrees of hypoalbuminemia, while the total serum protein concentration was variable.

One of the patients with carcinoma of the breast (E.T.) was studied during a cortisone induced remission of hypercalcemia and after the hypercalcemia had rapidly recurred ( $3 / 8$ sample) during an attempt at pallative estrogen treatment. The fall in total serum calcium during cortisone administration was accompanied by a proportionate decrease in both ultrafiltrable and non-ultrafiltrable calcium so that the per cent of ultrafiltrable calcium remained essentially constant and within the normal range. However, the extreme hypercalcemia induced by the estrogen administration was associated with an abnormally low percentage of ultrafiltrable calcium. A similar decrease in the ultrafiltrability of calcium in extreme hypercalcemia in man has been noted by others (3) and has been attributed to the formation of a "colloidal calcium-phosphate-protein complex" (11).

Patient F.D., with secondary hyperparathyroidism, had a congenital urinary tract anomaly and long standing renal disease. Typical destructive lesions of osteitis fibrosa cystica were seen in
X-rays of the hands and skull. Metastatic calcifications of arteries and soft tissues were prominent and the vertebrae showed the interesting combination of simultaneous destructive and sclerotic changes (12). His total serum calcium concentration and the concentration and percentage of ultrafiltrable calcium were normal. The significance of these observations will be left for the discussion after the results of the calcium infusion and parathyroid extract administration are presented.

\section{B. Hypocalcemia}

The hypocalcemic conditions studied have been arbitrarily divided into those without (Table I) and with (Table II) significant renal disease. Patient A.S. (Table I) was studied seven days after a sub-total thyroidectomy for toxic nodular goiter. Two days post-operatively he was found to have a positive Trousseau's sign and his serum calcium was $6.0 \mathrm{mg}$. per cent. Treatment with calcium, vitamin $\mathrm{D}$ and parathyroid extract was started and at the time of study he was receiving $12 \mathrm{Gm}$. of calcium gluconate and 75,000 units of vitamin D orally each day. Signs of latent tetany were still present. Both his total serum calcium and ultrafiltrable calcium were low, and they had decreased proportionately so that the per cent of ultrafiltrable calcium was similar to that found in the normal individuals. Note that his serum proteins were essentially normal.

Patient M.P. was studied before and during therapy for idiopathic hypoparathyroidism. Treat-

TABLE II

Ultrafiltration results and other pertinent data in patients with chronic renal disease

\begin{tabular}{|c|c|c|c|c|c|c|c|c|c|c|c|}
\hline \multirow[b]{2}{*}{ Subject } & \multirow[b]{2}{*}{ Age } & \multirow[b]{2}{*}{ Diagnosis } & \multicolumn{3}{|c|}{ Serum calcium* } & \multirow{2}{*}{$\underset{P^{*}}{\text { Serum }}$} & \multirow[b]{2}{*}{ BUN* } & \multirow{2}{*}{$\underset{\mathrm{CO}_{2} \dagger}{\text { Serum }}$} & \multicolumn{3}{|c|}{ Serum protein $\ddagger$} \\
\hline & & & Total & Ultrafil. & $\%$ U.F. & & & & Total & Alb. & Glob. \\
\hline $\begin{array}{l}\text { G. L. } \\
\text { C.S. } \\
\text { F. G. } \\
\text { D. F. } \\
\text { A. V. } \\
\text { N. O. } \\
\text { E. M. } \\
\text { T. G. } \\
\text { L.W. } \\
\text { R. W. } \\
\text { C. E. }\end{array}$ & $\begin{array}{l}48 \\
21 \\
75 \\
36 \\
51 \\
58 \\
77 \\
31 \\
56 \\
65 \\
88\end{array}$ & $\begin{array}{l}\text { Glomerulonephritis } \\
\text { Chronic pyelonephritis } \\
\text { Chronic pyelonephritis } \\
\text { Kimmelstiel-Wilson Syn. } \\
\text { Kimmelstiel-Wilson Syn. } \\
\text { Glomerulonephritis } \\
\text { Gouty nephritis } \\
\text { Chronic pyelonephritis } \\
\text { Chronic pyelonephritis } \\
\text { Glomerulonephritis } \\
\text { Nephrosclerosis }\end{array}$ & $\begin{array}{l}6.66 \\
7.84 \\
7.98 \\
8.03 \\
8.10 \\
8.12 \\
8.81 \\
9.03 \\
9.69 \\
5.58 \\
7.45\end{array}$ & $\begin{array}{l}5.58 \\
6.46 \\
6.19 \\
5.99 \\
6.46 \\
7.40 \\
6.53 \\
6.63 \\
7.70 \\
3.81 \\
5.04\end{array}$ & $\begin{array}{l}83.6 \\
82.4 \\
77.4 \\
74.6 \\
79.7 \\
91.2 \\
74.1 \\
73.5 \\
79.4 \\
68.3 \\
67.7\end{array}$ & $\begin{array}{r}12.0 \\
14.5 \\
6.2 \\
7.2 \\
3.9 \\
13.1 \\
6.5 \\
\\
5.4 \\
5.0 \\
6.7\end{array}$ & $\begin{array}{r}83 \\
148 \\
82 \\
107 \\
48 \\
210 \\
105 \\
63 \\
65 \\
122 \\
105\end{array}$ & $\begin{array}{l}21 \\
16 \\
16 \\
19 \\
20 \\
13 \\
15 \\
19 \\
19 \\
26 \\
26\end{array}$ & $\begin{array}{l}5.8 \\
4.8 \\
6.2 \\
7.0 \\
5.1 \\
7.5 \\
7.8 \\
7.6 \\
5.7 \\
5.7 \\
5.3\end{array}$ & $\begin{array}{l}3.1 \\
3.2 \\
3.8 \\
3.4 \\
2.5 \\
5.2 \\
5.4 \\
4.5 \\
3.1 \\
3.4 \\
3.0\end{array}$ & $\begin{array}{l}2.7 \\
1.6 \\
2.4 \\
3.6 \\
2.6 \\
2.3 \\
2.4 \\
3.1 \\
2.6 \\
2.3 \\
2.3\end{array}$ \\
\hline
\end{tabular}

* Values in mg. per cent.

+ Values in $\mathrm{mM}$ per $\mathbf{L}$.

$\ddagger$ Values in $\mathrm{Gm}$. per cent. 
ment with $3.75 \mathrm{mg}$. of A.T. 10 and $6 \mathrm{Gm}$. of calcium gluconate per day, orally, were started on $6 / 28$. It can be seen that the initial treatment with calcium and A.T. 10 was associated with a gradual rise in total serum calcium and little rise in ultrafiltrable calcium so that the per cent of ultrafiltrable calcium fell significantly. Vitamin $D$, 150,000 units per day, orally, was started on $7 / 1$ and the A.T. 10 discontinued. This patient continued to have intermittent severe convulsive episodes until $7 / 4$. It should be noted that on $7 / 17$, after more than two weeks of therapy with calcium and vitamin $D$, the ultrafiltrable calcium had increased only about $0.5 \mathrm{mg}$. per cent while the total calcium had increased $2 \mathrm{mg}$. per cent. However, when parathyroid hormone was administered during an Ellsworth-Howard test (13) (done on $7 / 17$ ), both the total calcium and ultrafiltrable calcium increased approximately $1 \mathrm{mg}$. per cent in a matter of five hours and the per cent of ultrafiltrable calcium remained constant.

Patient C.W. was admitted to the hospital for an acute exacerbation of steatorrhea. She had a very low total serum calcium on admission but a near normal concentration of ultrafiltrable calcium. Almost 90 per cent of the calcium in her serum was ultrafiltrable. At no time did she manifest signs or symptoms of latent tetany. Of significance is the fact that both the total protein and albumin concentrations in her serum were markedly reduced. Similarly, in patient J.A., with very low serum proteins due to liver disease, the per cent of ultrafiltrable calcium was 84 and the concentration of calcium in the serum ultrafiltrate was actually normal, although the total serum calcium was approximately $2 \mathrm{mg}$. per cent below normal.

In Table II we have grouped together the patients with hypocalcemia secondary to chronic renal disease. It is immediately apparent that the percentage of ultrafiltrable calcium in all except the last two patients (R.W. and C.E.) was abnormally high, regardless of the level of total calcium. Consequently, the concentration of calcium in the serum ultrafiltrates of these patients was within or near the normal range and, in several instances, was greater than normal. None of them, including R.W. and C.E., exhibited signs or symptoms of latent tetany.

Other pertinent blood chemistry determinations in these patients are also listed in the table. The blood urea nitrogen and serum inorganic phosphorus were elevated in all subjects but to varying degrees. Notice the inconsistent correlation between the levels of serum inorganic phosphorus and total serum protein and the degree of hypocalcemia. Although, in general, the serum proteins tended to be low, especially the albumin fraction, in three patients with a high percentage of ultrafiltrable calcium, N.O., E.M. and T.G., these were normal. Of possible significance is the fact that the carbon dioxide content of the serum was normal in R.W. and C.E., who showed no increase in the per cent of ultrafiltrable calcium, as contrasted with the other nine patients where it was uniformly decreased. In both these patients, alkali therapy had corrected the metabolic acidosis which had been present at the time of admission to the hospital. The implications of these findings will be discussed below.

\section{The serum ultrafiltrable calcium under ex- perimental conditions}

\section{A. Calcium infusion and parathyroid extract ad- ministration}

Our ultrafiltration results in disease states associated with hypercalcemia (Table I) and those of Hopkins, Connor, and Howard (3) indicate that the additional calcium is distributed proportionately between both ultrafiltrable and proteinbound calcium. Consequently, the percentage of the total serum calcium that is ultrafiltrable is generally within the range found for normal subjects. Since these clinical conditions represent, for the most part, chronic alterations in calcium and perhaps protein metabolism, it seemed of interest to compare them with a hypercalcemia acutely induced by the administration of "ionic calcium" or parathyroid extract. Figures 1 and 2 show the results of these experiments.

Nine $\mathrm{Gm}$. of calcium gluconate-heptonate in $900 \mathrm{ml}$. of 5 per cent dextrose in water $(890 \mathrm{mg}$. of calcium) was infused intravenously in a human subject over a three hour period and blood samples obtained at the times indicated in Figure 1. The total serum calcium was increased from 9.0 to $12.6 \mathrm{mg}$. per cent during the infusion, began to fall immediately after the infusion was stopped, and the next morning was still well above the pre- 


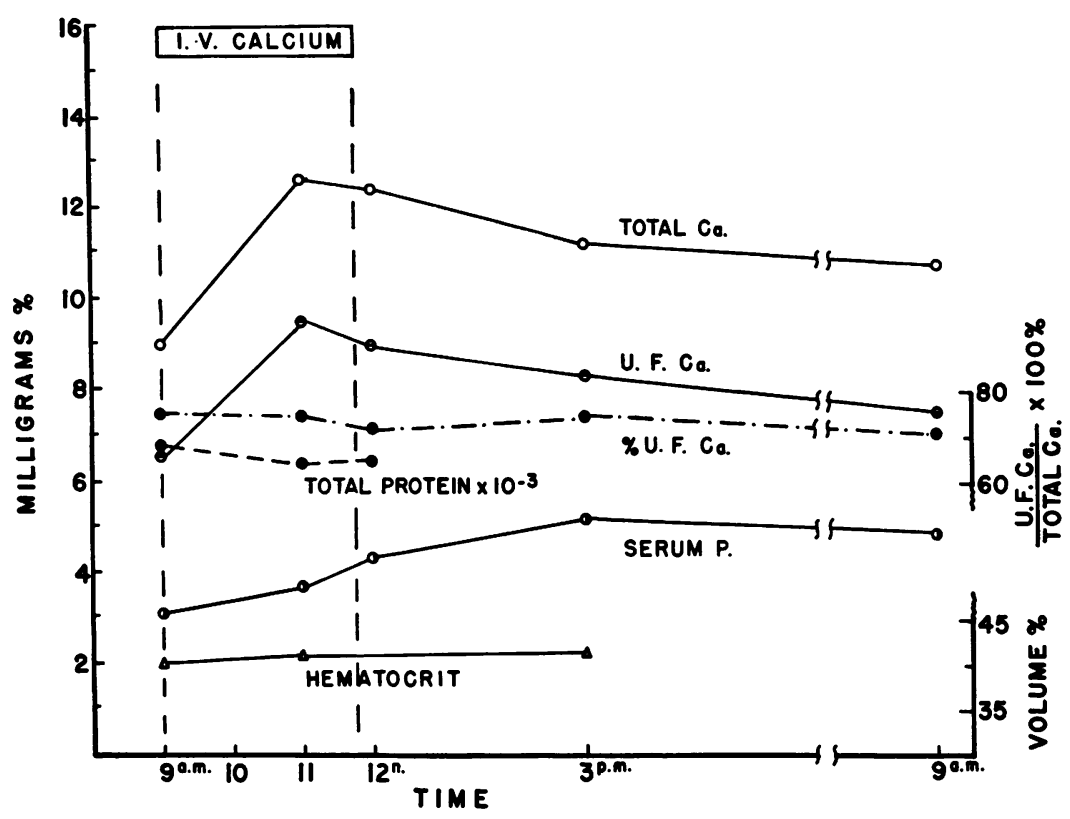

Fig. 1. The Effect of Intravenous Calcium Gluconate (14 mg. Calcium PER KG. B.W.) on Ultrafintrable Calcium

The right ordinate refers to the hematocrit and the per cent of ultrafiltrable calcium (\% U.F.Ca) and the left ordinate to all others.

injection level. Although the quantity of ultrafiltrable calcium also increased markedly, it should be noted that it remained a constant percentage of the total serum calcium. Consequently, the quan- tity of calcium bound by the serum proteins (i.e., non-ultrafiltrable) must also have increased proportionately although there was, if anything, a slight fall in the total protein concentration (no

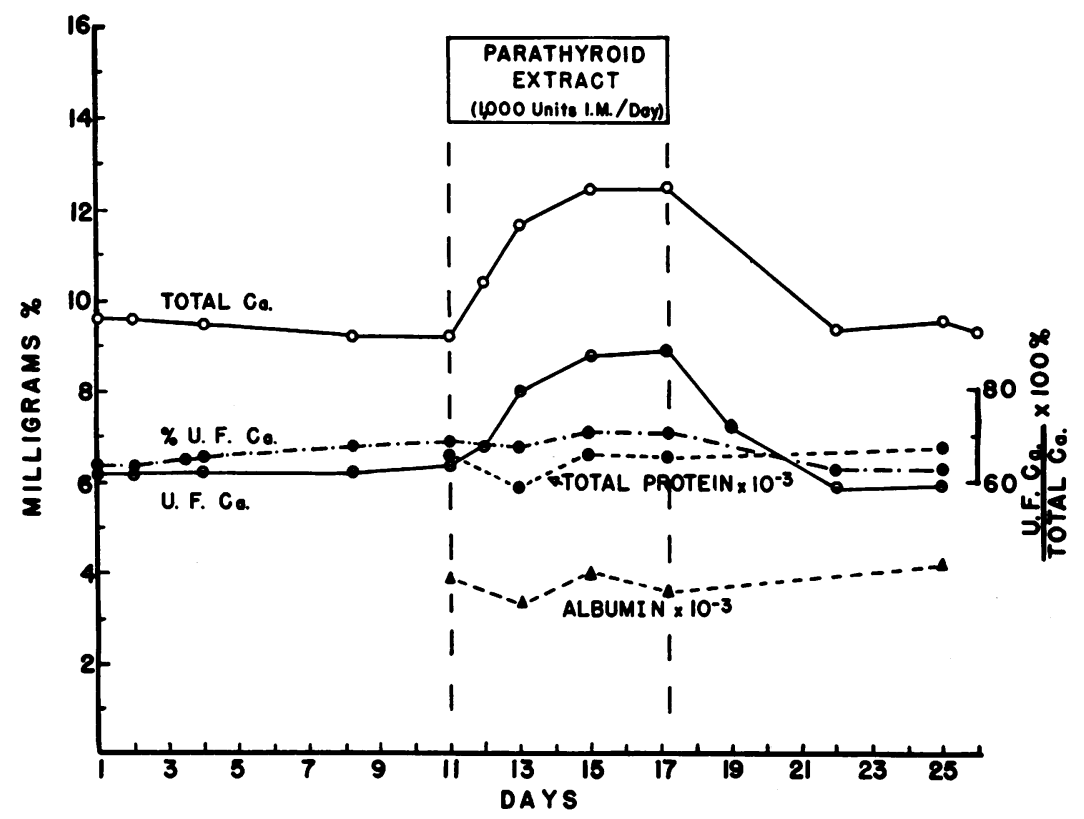

Fig. 2. The Effect of Parathyroid Extract on Ultrafiltrable Calcium The right ordinate refers to the per cent of ultrafiltrable calcium (\% U.F.Ca) and the left ordinate to all others. 


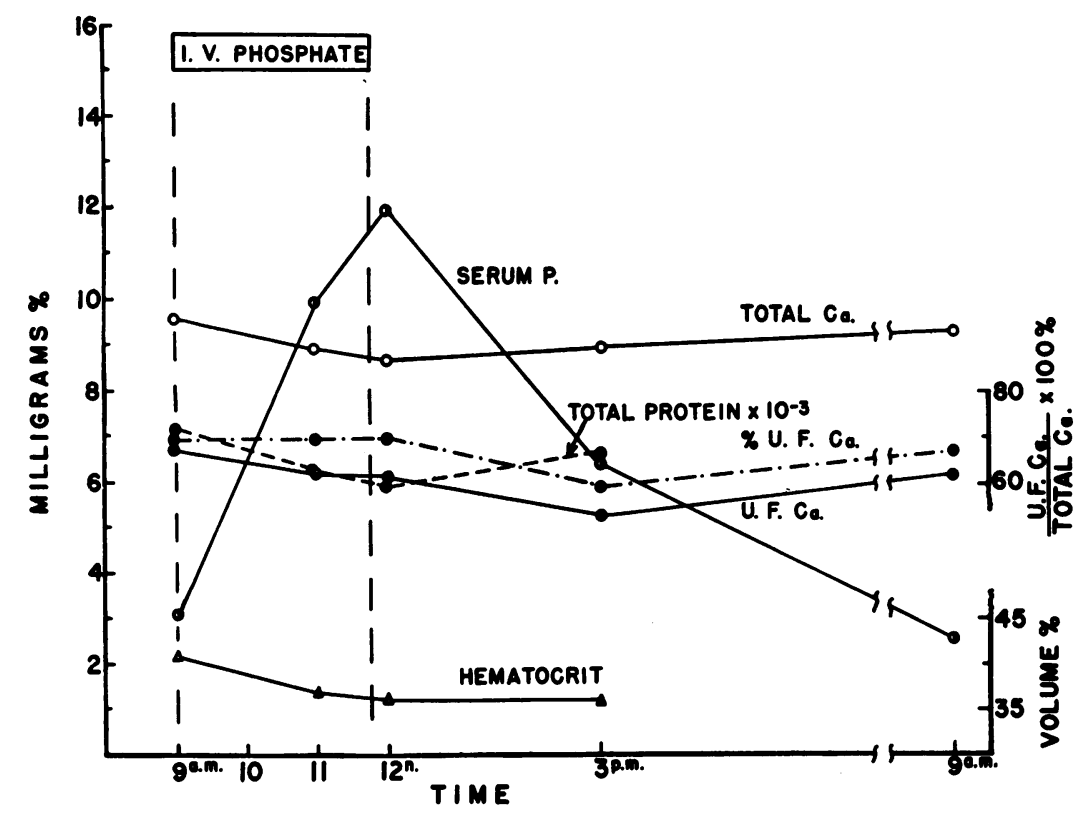

Fig. 3. The Effect of Intravenous Sodium Phosphate (34 mg. Phosphorus PER KG. B.W.) on Ultrafiltrable Calcium

The right ordinate refers to the hematocrit and the per cent of ultrafiltrable calcium (\% U.F.Ca) and the left ordinate to all others.

significant change in serum albumin: globulin [A/G] ratio occurred).

A gradual and persistent rise in serum inorganic phosphorus also was noted. This increased $2.1 \mathrm{mg}$. per cent, from a pre-injection level of 3.1 $\mathrm{mg}$. per cent to $5.2 \mathrm{mg}$. per cent at 3 p.m., and the following morning it was still elevated. The mechanism responsible for this increase in serum inorganic phosphorus when calcium is infused intravenously has not been explained satisfactorily (14). In our experiment, we also determined the total phosphorus content of the 9 a.m. and 3 p.m. serum samples after ashing. These showed a $2.8 \mathrm{mg}$. per cent increase over this time, from 11.6 to $14.4 \mathrm{mg}$. per cent. Thus, the rise in serum inorganic phosphorus characteristically seen during calcium infusion is not simply due to a redistribution among the various serum phosphorus fractions but is a specific increase.

The data obtained in the study of the hypercalcemia of experimentally induced hyperparathyroidism are shown in Figure 2. Five hundred units $(5 \mathrm{ml}$.) of parathormone (Lilly) were injected intramuscularly twice a day for six days. The subject was maintained on a constant dietary intake of calcium, phosphorus and nitrogen throughout the experiment. During the period of parathyroid extract administration, the total serum calcium increased to $12.5 \mathrm{mg}$. per cent and then promptly fell to control levels when the injections were discontinued. As in the calcium infusion experiment (Figure 1) the quantity of ultrafiltrable calcium also increased but there was no change in the percentage of ultrafiltrable calcium. Since the total serum protein and albumin concentration showed no significant changes, it is apparent that the additional calcium mobilized to serum by parathyroid extract was distributed proportionately between the ultrafiltrable and non-filtrable fractions of the serum calcium.

\section{B. Phosphate infusion}

The interrelationship of calcium and phosphorus in serum has received considerable attention, especially in relation to calcification and the mechanism of action of the parathyroid hormone (15). The finding of an abnormal increase in the percentage of ultrafiltrable calcium in most of our cases of renal disease with nitrogen and phosphorus retention (Table II), prompted us to study the effect of acute hyperphosphatemia per se on the distribution of calcium in serum. 
Nine hundred $\mathrm{ml}$. of a solution of monosodium and disodium phosphate ${ }^{4}$ containing 2.17 $\mathrm{Gm}$. of phosphorus was given intravenously to a human subject over a three hour period and the results are shown in Figure 3. Serum inorganic phosphorus was increased to $11.95 \mathrm{mg}$. per cent at the end of the infusion and then promptly fell. The following morning it was somewhat lower than the pre-injection level. This should be contrasted with the serum inorganic phosphorus values in the calcium infusion experiment (Figure 1). In the latter, serum inorganic phosphorus was still well above the pre-injection level on the morning following the calcium administration.

A fall in total serum calcium concentration occurred coincident with the rise in serum inorganic phosphorus, but this fall may be accounted for on the basis of hemodilution. Blood hematocrits done during the study showed a rapid decrease from a control level of 41 to 36 per cent at the end of the infusion and the total protein concentration fell from 7.2 to $6.0 \mathrm{Gm}$. per cent over the same period (no change in serum $A / G$ ratio occurred). The decrease in total serum calcium during the infusion was accompanied by a proportionate fall in ultrafiltrable calcium so that the per cent of the serum calcium that was ultrafiltrable remained constant throughout the period of marked hyperphosphatemia.

Our data indicate a sharp fall in ultrafiltrable calcium in the 3 p.m. sample. Since the total serum calcium was almost back to normal by this time, the percentage of ultrafiltrable calcium also shows a significant decrease (from 70 to 59 per cent). The following morning both the total calcium and the ultrafiltrable calcium had returned to pre-injection levels and the per cent of ultrafiltrable calcium was 67. Hopkins, Howard, and Eisenberg (16) reported a similar fall in ultrafiltrable calcium in vitro when phosphorus was added to serum in increasing amounts. These authors related this to the formation of a colloidal "calcium-phosphate-protein complex" (11) and suggested that "there might be a delayed equilibrium in the formation of a calcium-phosphate

4 The solution contained $2.14 \mathrm{Gm}$. of $\mathrm{NaH}_{2} \mathrm{PO}_{4} \cdot \mathrm{H}_{2} \mathrm{O}$ and $8.83 \mathrm{Gm}$. of $\mathrm{Na}_{2} \mathrm{HPO}_{4}$ per $\mathrm{L}$. of 5 per cent dextrose in water. The sodium concentration, determined by flame photometry, was $136 \mathrm{mEq}$. per $\mathrm{L}$. and the $\mathrm{pH}$ was 7.36 when measured on a Beckman model $\mathrm{G} \mathrm{pH}$ meter. 'complex,' as there is in precipitation of calcium phosphate from supersaturated solutions." Interestingly, the apparent decrease in ultrafiltrable calcium in our experiment occurred sometime after the maximum elevation in serum inorganic phosphorus had been attained.

\section{Citrate infusion}

Of the ultrafiltrable anionic complexers of calcium in serum, citrate has received most attention because of its possible relationship to calcium metabolism in bone and kidney. It has been repeatedly demonstrated that a rise or fall in serum calcium concentration is generally associated with parallel changes in serum citrate levels (17). Chang and Freeman also found (18) that the intravenous administration of sodium citrate (given to dogs at the rate of $0.67 \mathrm{mg}$. per $\mathrm{Kg}$. body weight per minute for two hours) caused an increase in total serum calcium concentration. On the other hand, hypercitremia from rapid transfusion of citrated whole blood has been associated with signs and symptoms of tetany, presumably on the basis of acute depression of ionized calcium (19).

We investigated the effects of an intravenous infusion of approximately $0.5 \mathrm{mg}$. of citrate ion per $\mathrm{Kg}$. body weight per minute on total and ultrafiltrable calcium in a human subject. ${ }^{5}$ Seven hundred ml. of a 5 per cent dextrose in water solution containing $9.10 \mathrm{Gm}$. of sodium citrate (5.85 Gm. of citrate ion and $134 \mathrm{mEq}$. per L. of sodium) was infused intravenously over a three hour period and blood samples were obtained before, during and after the infusion (Figure 4). Serum citrate was increased about fivefold to 15.5 mg. per cent. The rapidity of citrate metabolism in vivo (21) is demonstrated by the fact that three hours later the serum citrate concentration had returned to the pre-injection level.

Both the total serum protein concentrations and the blood hematocrits fell rapidly during the infusion, indicating acute hemodilution. Total serum

\footnotetext{
5 In a recent review of citrate intoxication (20), it was stated that citrate injections at the rate of $1.0 \mathrm{mg}$. per $\mathrm{Kg}$. body weight per minute in man may lead to toxic manifestations, although the rate usually attained in infants who developed tetany during exchange transfusion has been between 5 and $10 \mathrm{mg}$. of citrate per $\mathrm{Kg}$. body weight per minute.
} 


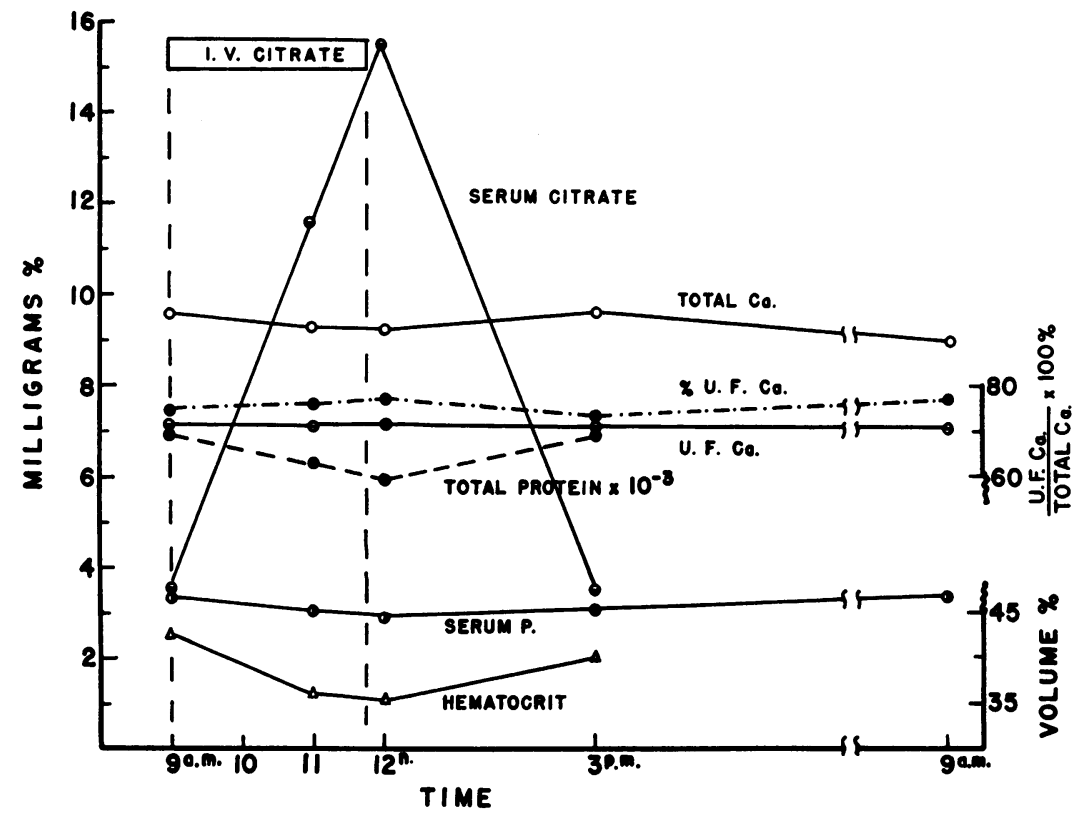

Fig. 4. The Effect of Intravenous Sodium Citrate (0.5 mg. Citrate Ion Per KG. B.W. Per Minute) on Ultrafiltrable Calcium

The right ordinate refers to the hematocrit and the per cent of ultrafiltrable calcium (\% U.F.Ca) and the left ordinate to all others.

calcium decreased, but not as much as might be expected on the basis of the hemodilution (cf., the fall in total serum calcium in the phosphate infusion experiment shown in Figure 3 ). Since Chang and Freeman (18) used relatively small volumes of fluid to induce hypercitremia in their dogs, the hemodilution in our experiment could have masked an actual increase in serum calcium concentration. If the recently suggested hypothesis $(22,23)$ that citrate has a primary role in the mobilization of calcium from bone to the extracellular fluid is correct, high blood citrate levels might be expected to increase serum calcium by causing a more rapid release of calcium from bone.

By using the dissociation constant of calcium citrate, the quantities of citrate bound calcium in serum may be calculated. ${ }^{6}$ At the initial serum

- This calculation can be made by utilizing the equation:

$$
\left[\mathrm{Ca} \mathrm{Cit}{ }^{-}\right]=\frac{\mathrm{K} \cdot \mathrm{T}\left[\mathrm{Ca}^{++}\right]}{1+\mathrm{K}\left[\mathrm{Ca}^{++}\right]}
$$

where $\mathrm{K}$ equals stability constant of the calcium citrate complex and $\mathrm{T}$ equals total citrate. This equation is obtained by solving simultaneously the two equations:

$$
\mathrm{K}=\frac{\left[\mathrm{Ca} \mathrm{Cit}^{-}\right]}{\left[\mathrm{Ca}^{++}\right]\left[\mathrm{Cit}^{-}\right]} \text {and } \mathrm{T}=\left[\mathrm{Ca} \mathrm{Cit}^{-}\right]+\left[\mathrm{Cit}^{-}\right]
$$

The values $1.25 \mathrm{mM}$ per $\mathrm{L}$. for $\left[\mathrm{Ca}^{++}\right]$and $1.66 \times 10^{3}$ for $\mathrm{K}$, of Hastings, McLean, Eichelberger, Hall, and Da Costa (24), were used in our calculations. citrate concentration of $3.5 \mathrm{mg}$. per cent approximately $0.5 \mathrm{mg}$. per cent of calcium is complexed as diffusible calcium citrate. An increase in serum citrate concentration to $15.5 \mathrm{mg}$. per cent (12 o'clock noon level) will result in a minimum of $2 \mathrm{mg}$. per cent of citrate complexed calcium. The increase in calcium bound to citrate must be supplied from the pool consisting of protein bound calcium, ionic calcium, and complexed but diffusible calcium. An appreciable decrease in protein bound calcium would result in an increase in ultrafiltrable calcium. As can be seen in Figure 4, only a minimal increase in the percentage of ultrafiltrable calcium occurred even at the height of the hypercitremia. Thus, most of the additional calcium complexed by citrate must have come from the diffusible forms of calcium. "Ionic" calcium, because of its relative abundance in serum $(25,26)$, would undoubtedly be most affected.

\section{DISCUSSION}

Ultrafiltration results may be expressed in two ways: 1) as the actual concentration of calcium in mg. per cent in the ultrafiltrates of whole serum, or 2) as the percentage of the total calcium 
in the serum that is ultrafiltrable. Most previous authors, including ourselves, have emphasized either one or the other (rarely both) in their writings on ultrafiltrable calcium in normal and disease states. We believe that both methods of expressing ultrafiltration results are equally meaningful but, as discussed below, variations from normal values in the percentage or concentration of ultrafiltrable calcium are dependent upon different physiological mechanisms.

McLean and Hastings (27) postulated in 1935 that the distribution of calcium in serum, between ultrafiltrable and non-ultrafiltrable forms, is governed by a purely physical chemical process: the mass action relationship $\mathrm{Ca}^{++}+$Prot $\leftrightharpoons \mathrm{CaPro}-$ teinate. Our findings, and those of others $(3,14)$, in hypercalcemia, whether secondary to a disease process (Table I) or experimentally induced by the administration of calcium (Figure 1) or parathyroid extract (Figure 2), support this hypothesis. Calcium added to serum in vivo under any of these circumstances led not only to an increase in ultrafiltrate calcium but to a proportionate increase in protein bound calcium so that the per cent of calcium which was ultrafiltrable was not altered significantly. This relationship has also been clearly demonstrated, in vitro, by adding increasing amounts of calcium to serum before ultrafiltration (16).

It is generally accepted that the parathyroid glands are intimately concerned with the maintenance of a normal serum calcium concentration. Although the precise physiological mechanisms involved are still incompletely understood, it is now believed that the parathyroids are concerned with the equilibrium between calcium in bone and extracellular fluid (28-31). Once in the serum, however, the calcium released from bone under parathyroid influence also obeys the law of mass action in its reaction with serum proteins. Thus, when the bone: extracellular fluid equilibrium was disturbed by the administration of parathyroid extract (Figure 2, and M.P., Table I) both the ultrafiltrable calcium and the total calcium increased proportionately so that the per cent of ultrafiltrable calcium was not altered, while in hypoparathyroidism (A.S. and M.P., Table I of our data, and Table III of Hopkins, Connor, and Howard [3]), there was a proportionate decrease in both these calcium fractions. On the other hand, hypoproteinemia (C.N. and J.A., Table I), with presumably normal parathyroid function, was associated with a low total serum calcium, a normal or near normal concentration of ultrafiltrable calcium and a high percentage of ultrafiltrable calcium. These considerations indicate that the concentration of calcium in ultrafiltrates of serum is determined by the bone: extracellular fluid calcium equilibrium, while the total serum calcium, and consequently the per cent of ultrafiltrable calcium, is secondarily determined by mass law relationships in serum or plasma. It follows that the total calcium in serum only reflects the level necessary to maintain the concentration of ultrafiltrable or ionized calcium determined by the parathyroid controlled bone: extracellular fluid equilibrium on the one hand, and serum mass law relationship on the other.

Both our data (Table I) and that of Hopkins, Connor, and Howard (3) showed that the hypercalcemia of malignant disease, Boeck's sarcoidosis, and vitamin D intoxication was associated with elevated concentrations of ultrafiltrable calcium, while the percentage of the total serum calcium that was ultrafiltrable was generally within the range found for normal subjects when serum proteins were essentially normal. Furthermore, when the hypercalcemia in one patient (E.T., Table I) was partially corrected with cortisone, the ultrafiltrable and total calcium fell proportionately and there was no change in the percentage of ultrafiltrable calcium. Similar findings in cortisone or adrenocorticotropic hormone therapy of hypercalcemia were reported by Hopkins and her associates (3). We interpret these observations to mean that the calcium disturbance in these disease states is also due to a primary alteration in the bone: extracellular fluid calcium equilibrium (which can be corrected with cortisone) with secondary changes in the total serum calcium. In this connection, it is of interest that several authors have recently reported $(32,33)$ cases of hypercalcemia in malignant disease without evidence of tumor invasion of bone (and with normal parathyroid glands at autopsy) although the hypercalcemia is usually ascribed to bone metastasis with rapid destruction of bone and release of calcium into the circulation.

From the above discussions, one may postulate that an alteration in the concentration of ultra- 
filtrable calcium means some disturbance (albeit non-specific) in the calcium equilibrium at the skeletal level, while an abnormal percentage of ultrafiltrable calcium indicates an alteration in calcium-protein relationships in serum.

It is well known that hypocalcemia is often associated with chronic renal disease but that tetany is infrequently seen. The former has been attributed to hypoproteinemia and hyperphosphatemia, and the latter to acidosis, all of which frequently accompany these disease states. We could not correlate the degree of hypocalcemia in our patients with renal disease with the level of serum inorganic phosphorus and, although serum proteins tended to be low in the patients studied, this did not necessarily agree with the total calcium level. Our data, however, demonstrated (Table II) that in all but two of the patients studied, the percentage of the total serum calcium that was ultrafiltrable was abnormally high. Consequently, the quantity of ultrafiltrable calcium was essentially normal or even greater than normal (thus accounting for the clinical observations that tetany occurs infrequently in renal disease) while the amount of calcium bound to protein was decreased irrespective of the level of total calcium. The decrease in protein bound calcium was responsible for the hypocalcemia in most of these cases when the latter was present.

A decrease in protein bound calcium may occur because of : 1) a fall in concentration of serum protein, 2) a specific alteration in the binding ability of the proteins, or 3 ) a decrease in the ionized calcium level. In our patients, the high percentage of ultrafiltrable calcium did not correlate well with the level of total proteins or albumin in the serum. One or both of the other factors must also have been involved in decreasing protein bound calcium, but from the data at hand, we could not define the exact mechanisms.

It has been repeatedly demonstrated that $\mathrm{pH}$ will affect the binding ability of serum proteins $(34,35)$. However, as pointed out in our previous publication (1), the $\mathrm{pH}$ change accompanying the metabolic acidosis of renal disease should have only a minor effect on the ultrafiltrability of calcium in serum. Yet it seems significant that the two patients with low concentrations and normal percentages of ultrafiltrable calciums (R.W. and C.E.) were those whose "metabolic acidosis" had been treated and corrected, at least as judged by the serum carbon dioxide content. Some other change in chronic renal disease aside from the serum $\mathrm{pH}$ per $s e$, but associated with the clinical state called "metabolic acidosis," could conceivably alter the ability of the serum proteins to bind calcium and contribute to the maintenance of a normal concentration of ultrafiltrable calcium.

The possibility that patients with renal disease and azotemia and hyperphosphatemia actually have low ionized calciums because of abnormal amounts of citrate in the blood was not substantiated (36). Total organic acids, however, were not measured, and we do not know the quantity of "unmeasured anions" (37) in our patients. It is possible that other abnormal calcium complexers are present which depress the ionic calcium and, therefore, protein bound calcium specifically. A detailed investigation of calcium-protein interrelationships in normal and disease states is in progress and will be reported in a separate communication.

\section{SUMMARY}

1. The ultrafiltrability of serum calcium in human subjects was determined: a) in disease states associated with hypercalcemia and hypocalcemia, and $b$ ) before, during and after the parenteral administration of calcium, citrate, phosphate and parathyroid extract.

2. An increase in serum calcium, whether due to a disease process or secondary to calcium or parathyroid extract administration, caused a proportionate increase in both ultrafiltrable and protein bound calcium so that no significant change occurred in the percentage of ultrafiltrable calcium.

3. Hypocalcemia was accompanied by normal or, more frequently, a high percentage of ultrafiltrable calcium. The latter was generally associated with hypoproteinemia, and the former with normal plasma proteins. This relationship, however, did not always hold in the hypocalcemia of renal disease.

4. In renal disease, a high percentage of ultrafiltrable calcium was almost invariable, regardless of the level of serum proteins so that the actual quantity of ultrafiltrable calcium approached normal. A specific alteration in the amount of calcium bound to serum proteins appeared to be present. 
5. Hyperphosphatemia and hypercitremia had specific, but transient, effects on ultrafiltrable calcium.

6. By the application of physical chemical principles, abnormalities in the concentration of ultrafiltrable calcium in serum have been ascribed to disturbances in the bone: extracellular fluid calcium equilibrium, while abnormalities in the percentage of ultrafiltrable calcium (ratio of ultrafiltrable to total serum calcium) have been related to alterations in calcium-protein interrelationships in serum. In renal disease with disturbances in calcium metabolism, no simple mechanism correlated with the ultrafiltrable calcium values obtained.

\section{REFERENCES}

1. Toribara, T. Y., Terepka, A. R., and Dewey, P. A., The ultrafiltrable calcium of human serum. I. Ultrafiltrable methods and normal values. J. Clin. Invest., 1957, 36, 738.

2. Herbert, F. K., The total and diffusible calcium of serum and the calcium of cerebrospinal fluid in human cases of hypocalcaemia and hypercalcaemia. Biochem. J., 1933, 27, 1978.

3. Hopkins, T. R., Connor, T. B., and Howard, J. E., Ultrafiltration studies on calcium and phosphorus in pathological human serum. Bull. Johns Hopkins Hosp., 1953, 93, 249.

4. Toribara, T. Y., Dewey, P. A., and Warner, H., Flame photometric determination of calcium in biological material. Effect of low level impurities from calcium oxalate precipitation. Anal. Chem., 1957, 29, 540.

5. Fiske, C. H., and Subbarow, Y., The colorimetric determination of phosphorus. J. Biol. Chem., 1925, 66, 375.

6. Chen, P. S., Toribara, T. Y., and Warner, H., Microdetermination of phosphorus. Anal. Chem., 1956, 28, 1756.

7. Van Slyke, D. D., and Neill, J. M., The determination of gases in blood and other solutions by vacuum extraction and manometric measurement. I. J. Biol. Chem., 1924, 61, 523.

8. Van Slyke, D. D., and Cullen, G. E., The determination of urea by the urease method. J. Biol. Chem., 1916, 24, 117

9. Jacox, R. F., Quantitative fractionation of component proteins of human serum with cationic detergents. J. Clin. Invest., 1953, 32, 661.

10. Ettinger, R. H., Goldbaum, L. R., and Smith, L. H., Jr., A simplified photometric method for the determination of citric acid in biological fluids. J. Biol. Chem., 1952, 199, 531.

11. Grollman, A., The condition of the inorganic phosphorus of the blood with special reference to the calcium concentration. J. Biol. Chem., 1927, 72, 565.

12. Crawford, T., Dent, C. E., Lucas, P., Martin, N. H., and Nassim, J. R., Osteosclerosis associated with chronic renal failure. Lancet, 1954, 2, 981.

13. Ellsworth, R., and Howard, J. E., Studies on the physiology of the parathyroid glands. VII. Some responses of normal human kidneys and blood to intravenous parathyroid extract. Bull. Johns Hopkins Hosp., 1934, 55, 296.

14. Howard, J. E., Hopkins, T. R., and Connor, T. B., On certain physiologic responses to intravenous injections of calcium salts into normal, hyperparathyroid and hypoparathyroid persons. J. Clin. Endocrinol. \& Metab., 1953, 13, 1.

15. Albright, F., and Reifenstein, E. C., Jr., Parathyroid Glands and Metabolic Bone Disease. Baltimore, Williams \& Wilkins Co., 1948.

16. Hopkins, T., Howard, J. E., and Eisenberg, H., Ultrafiltration studies on calcium and phosphorus in human serum. Bull. Johns Hopkins Hosp., $1952,91,1$.

17. Dixon, T. F., and Perkins, H. R., Citric acid and bone in The Biochemistry and Physiology of Bone, G. H. Bourne, Ed. New York, Academic Press Inc., 1956, p. 313.

18. Chang, T. S., and Freeman, S., Citric acid and its relation to serum and urinary calcium. Am. J. Physiol., 1950, 160, 330.

19. Wexler, I. B., Pincus, J. B., Natelson, S., and Lugovoy, J. K., III. The fate of citrate in erythroblastotic infants treated with exchange transfusion. J. Clin. Invest., 1949, 28, 474.

20. Yendt, E. R., Citrate intoxication. Canad. M. A. J., 1957, 76, 141.

21. Saffran, M., and Denstedt, O. R., The effect of intravenously injected citrate on the serum ionized calcium in the rabbit. Canad. J. M. Sc., 1951, 29, 245.

22. Neuman, W. F., Firschein, H., Chen, P. S., Jr., Mulryan, B. J., and DiStefano, V., On the mechanism of action of parathormone. J. Am. Chem. Soc., 1956, 78, 3863.

23. Firschein, H., Martin, G., Mulryan, B. J., Strates, B., and Neuman, W. F., Concerning the mechanism of action of parathyroid hormone. I. Ion-gradients. J. Am. Chem. Soc. In press.

24. Hastings, A. B., McLean, F. C., Eichelberger, L., Hall, J. L., and Da Costa, E., The ionization of calcium, magnesium, and strontium citrates. J. Biol. Chem., 1934, 107, 351.

25. McLean, F. C., and Hastings, A. B., The state of calcium in the fluids of the body. I. The conditions affecting the ionization of calcium. J. Biol. Chem., 1935, 108, 285.

26. Neuman, W. F., and Neuman, M. W., The Chemical Dynamics of Bone Mineral. Chicago, Univ. of Chicago Press. In press, Chap. 1.

27. McLean, F. C., and Hastings, A. B., Clinical estimation and significance of calcium-ion concentra- 
tions in the blood. Am. J. M. Sc., 1935, n.s. 189, 601.

28. Neuman, W. F., and Neuman, M. W., Emerging concepts of the structure and metabolic functions of bone. Am. J. Med., 1957, 22, 123.

29. Howard, J. E., Present knowledge of parathyroid function, with especial emphasis upon its limitations in Ciba Foundation Symposium on Bone Structure and Metabolism, G. E. W. Wolstenholme and C. M. O'Connor, Eds. Boston, Little, Brown and Co., 1956, p. 206.

30. Copp, D. H., Calcium and phosphorus metabolism. Am. J. Med., 1957, 22, 275.

31. McLean, F. C., and Urist, M. R., Bone; An Introduction to the Physiology of Skeletal Tissue. Chicago, Univ. of Chicago Press, 1955, p. 72.

32. Connor, T. B., Thomas, W. C., Jr., and Howard, J. E., The etiology of hypercalcemia associated with lung carcinoma (abstract). J. Clin. Invest., 1956, 35, 697.

33. Plimpton, C. H., and Gellhorn, A., Hypercalcemia in malignant disease without evidence of bone destruction. Am. J. Med., 1956, 21, 750.

34. Carr, C. W., Studies on the binding of small ions in protein solutions with the use of membrane electrodes. II. The binding of calcium ions in solutions of bovine serum albumin. Arch. Biochem. \& Biophys., 1953, 43, 147.

35. Katz, S., and Klotz, I. M., Interactions of calcium with serum albumin. Arch. Biochem. \& Biophys., 1953, 44, 351.

36. Terepka, A. R., and Mulryan, B. J. Unpublished data.

37. Schwartz, W. B., and Relman, A. S., Acidosis in renal disease. New Eng. J. Med., 1957, 256, 1184. 